\title{
The effect of herbicides on yield of winter wheat depending on selected agronomic factors
}

\author{
Wpływ herbicydów na plonowanie pszenicy ozimej \\ w zależności od wybranych czynników agrotechnicznych
}

\author{
Marek Urban ${ }^{1}$, Paweł Kazikowski ${ }^{2}$
}

\begin{abstract}
Summary
The aim of the study executed with the split-block method with 4 replications and conducted at the Experimental Station BASF Ltd. in Pągów in the years 2009-2011 was to evaluate the effect of different doses of herbicides on the reduction of weed, grain yield and structure of two varieties of winter wheat depending on the time of sowing. The studies tested two morphologically different varieties, Nutka and Ludwig. It has been shown that weed abundance on the control plots depends on both the sowing date as well as the cultivated variety of wheat. In the area where wheat was sown at the optimum sowing time 205.9 weeds per $\mathrm{m}^{2}$ occurred on plots with Ludwig variety, and 246.9 per $\mathrm{m}^{2}$ with Nutka while in the delayed sowing, 134.9 per $\mathrm{m}^{2}$ and 158.5 per $\mathrm{m}^{2}$, respectively. The effectiveness of the full doses of herbicides was much higher than of these reduced by $50 \%$, which demonstrates the high sensitivity of weed species occurring in the study for active substances of herbicides. Based on the conducted survey it was found that both varieties of wheat reacted differently to grain yield on the control objects from the ones sprayed with herbicides. On the control plots, wheat sown at the optimal period produced smaller yields than wheat from the delayed sowing, while on the plots protected with herbicides the relations were inverse. In both sowing dates within the combination sprayed with herbicides no differences were observed in yielding wheat. It has been shown, however, that the variety Ludwig had a by $5.8 \%$, and the variety Nutka by $16.7 \%$ higher yield from the timely sown crops than from the delayed sown. Analysis of the structure of yield has shown that grain yield depends in the highest degree on plant density per $\mathrm{m}^{2}$, and to a lesser extent on the weight of 1,000 grains, whereas the number of grains per spike remained unchanged.
\end{abstract}

Key words: winter wheat; varieties; yield; dose of herbicides; grain quality; sowing dates

\section{Streszczenie}

Celem doświadczeń założonych metodą split-block w 4 powtórzeniach, które przeprowadzono w Stacji Doświadczalnej BASF Sp. z o.o. w Pągowie, w latach 2009-2011, było określenie wpływu zróżnicowanych dawek herbicydów na redukcję zachwaszczenia oraz wielkość plonów ziarna i jego strukturę dotyczące dwóch odmian pszenicy ozimej w zależności od ich terminu siewu. W badaniach testowano różniące się pod względem morfologicznym odmiany: Ludwig i Nutka. Wykazano, że stan zachwaszczenia na poletkach kontrolnych zależał zarówno od terminu siewu, jak też od uprawianych odmian pszenicy. W łanie pszenicy odmiany Ludwig zasianej w terminie optymalnym wystąpiło 205,9 sztuk chwastów na m², a odmiany Nutka - 246,9 szt./m², natomiast w zasiewach opóźnionych odpowiednio: Ludwig - 134,9 i Nutka - 158,5 szt./m². Skuteczność herbicydów zastosowanych w pełnych dawkach była niewiele wyższa od dawek pomniejszonych o 50\%, co świadczy o dużej wrażliwości występujących w doświadczeniu gatunków chwastów na substancje czynne środków chwastobójczych. Stwierdzono, że obie testowane odmiany pszenic, w zależności od terminu siewu, zareagowały inaczej wysokością plonu ziarna z obiektów kontrolnych niż opryskiwanych herbicydami. Na poletkach kontrolnych pszenica pochodząca z zasiewów wykonanych w terminie optymalnym miała plony niższe niż z zasiewów opóźnionych, natomiast na chronionych herbicydami, powyższe relacje ukształtowały się odwrotnie. W obu terminach siewu, w obrębie kombinacji z zastosowaniem środków chwastobójczych, nie wystąpiły różnice w plonowaniu pszenicy. Wykazano, że odmiana Ludwig miała plony o 5,8\%, a odmiana Nutka o $16,7 \%$ wyższe z zasiewów optymalnych niż opóźnionych. Analiza struktury plonu dowiodła, że wielkość plonu ziarna w najwyższym stopniu zależała od obsady roślin na $\mathrm{m}^{2}$, w mniejszym od masy 1000 ziaren, a liczba ziaren w kłosie pozostała bez zmian.

Słowa kluczowe: pszenica ozima; odmiany; plon; dawki herbicydów; jakość ziarna; terminy siewów

\footnotetext{
1 Instytut Ochrony Roślin - Państwowy Instytut Badawczy

Terenowa Stacja Doświadczalna

Milicka 21, 55-100 Trzebnica

TSD Trzebnica@iorpib.poznan.pl

${ }^{2}$ BASF Polska Sp. z o.o.

Al. Jerozolimskie 154, 02-326 Warszawa
} 


\section{Wstęp / Introduction}

Głównym czynnikiem ograniczającym potencjalne możliwości plonotwórcze pszenicy ozimej jest zachwaszczenie, stąd $\mathrm{w}$ technologii uprawy wzrasta znaczenie zwalczania chwastów (Skrzypczak i Adamczewski 2002). Poczynione w praktyce rolniczej obserwacje wskazuja, że odmiany roślin zbożowych charakteryzują się zróżnicowaną reakcją w stosunku do flory segetalnej. O zdolnościach konkurencyjnych odmian wobec chwastów decyduje tempo wschodów i wzrostu roślin, cechy morfologiczne i fizjologiczne, szybkość zacieniania powierzchni gleby, liczba wytworzonych pędów bocznych, a w szczególności wysokość łanu rośliny uprawnej (FeledynSzewczyk i Duer 2005; Parylak i wsp. 2006). Wykorzystanie naturalnych zdolności konkurencyjnych odmian pszenicy ozimej może stać się ważną przesłanką dla obniżenia aplikowanych dawek herbicydów w stosunku do zalecanych, $\mathrm{z}$ jednoczesnym zachowaniem wysokiej skuteczności chwastobójczej. Dowodzą tego wyniki badań Domaradzkiego (2006), Kraski (2006) oraz Pietrygi i Drzewieckiego (2007), którzy udowodnili, że zmniejszenie nawet o 50\% dawek herbicydów w uprawie pszenicy ozimej, skutkowało wysokim efektem chwastobójczym, gwarantującym osiagnnięcie wysokich plonów ziarna, a także przyczyniło się do zmniejszenia kosztów produkcji i ograniczenia skażenia środowiska naturalnego.

Celem badań była ocena wpływu pełnych oraz o połowę ograniczonych dawek wybranych herbicydów na redukcję zachwaszczenia oraz wysokość i strukturę plonu ziarna dwóch odmian pszenicy ozimej.

\section{Materiały i metody / Materials and methods}

Doświadczenia polowe wykonywano w latach 2009-2011, w Stacji Doświadczalnej BASF Sp. z o.o. w Pagowie. Badania przeprowadzono metodą pasów prostopadłych (split-block) w 4 powtórzeniach na poletkach o powierzchni $10,5 \mathrm{~m}^{2}$, które zlokalizowano na glebie gliniastej, klasy II, należącej do kompleksu pszennego bardzo dobrego. Materiał badawczy stanowiły różniące się pod względem morfologicznym dwie odmiany pszenicy ozimej: Ludwig i Nutka, które wysiewano w terminie optymalnym i o miesiąc opóźnionym. W każdym roku badań poza kombinacją kontrolną, na obu odmianach pszenicy, w poszczególnych terminach siewu, zastosowano następujące herbicydy: Maraton $375 \mathrm{SC}$ (pendimentalina + izoproturon) w dawkach 2,0 i 4,0 1/ha, Biathlon 71,4 WG (tritosulfuron) + Apyros 75 WG (sulfosulfuron) w dawkach $0,025+0,0065$ i $0,05+0,013 \mathrm{~kg} / \mathrm{ha}$ oraz Mocarz $75 \mathrm{WG}$ (dikamba + tritosulfuron) + Apyros $75 \mathrm{WG}$ (sulfosulfuron) w dawkach 0,075 + 0,0065 i 0,15+0,013 kg/ha.

Herbicyd Maraton 375 SC aplikowano bezpośrednio po zasiewie, natomiast pozostałe środki chwastobójcze wiosną, po ruszeniu wegetacji pszenicy. Zabiegi herbicydowe wykonano opryskiwaczem Gloria 141, wyposażonym w 6 sztuk rozpylaczy płaskostrumieniowych typu Tee Jet LU9002, rozstawionych na belce o szerokości roboczej $1,5 \mathrm{~m}$, przy wydatku cieczy użytkowej $250 \mathrm{l} / \mathrm{ha}$ i ciśnieniu $0,2 \mathrm{MPa}$. Przedplonem dla pszenicy corocznie był rzepak ozimy. Pozostałe zabiegi wykonano zgodnie z obowiązującymi zaleceniami agrotechnicznymi. Zaprawione nasiona pszenicy wysiewano siewnikiem Hege 140 o szerokości roboczej 1,5 $\mathrm{m}$ i rozstawie rzędów $12,5 \mathrm{~cm}$. Dla obu terminów siewu przyjęto stałą normę wysiewu nasion wynoszącą 320 sztuk ziarniaków na $\mathrm{m}^{2}$. W każdym roku badań zastosowano stałe nawożenie mineralne: $\mathrm{N}-223$, $\mathrm{P}-92 \mathrm{i} \mathrm{K}-120 \mathrm{~kg} / \mathrm{ha}$. Nawozy fosforowe i potasowe wysiewano bezpośrednio przed zasiewem pszenicy, natomiast azotowe w 4 dawkach: przed siewem pszenicy (BBCH 00) - $36 \mathrm{~kg} / \mathrm{ha}$; wiosna, przed ruszeniem wegetacji $(\mathrm{BBCH}$ $21 / 23)-68 \mathrm{~kg} / \mathrm{ha}$; w fazie strzelania w źdźbło (BBCH $30 / 31$ ) - $68 \mathrm{~kg} / \mathrm{ha}$ i po wykłoszeniu pszenicy (BBCH 59) $51 \mathrm{~kg} / \mathrm{ha}$. Niezależnie od aplikowanych herbicydów, na całej powierzchni doświadczenia prowadzono chemiczne zwalczanie chorób grzybowych i szkodników oraz stosowano regulatory wzrostu.

Po 3-4 tygodniach od daty wiosennego stosowania środków chwastobójczych oceniono metodą ramkową skuteczność chwastobójczą herbicydów porównując te wartości do obiektów kontrolnych, nietraktowanych środkami chemicznymi. Ocenę fitotoksycznego oddziaływania herbicydów na rośliny pszenicy określono w procentach, w porównaniu do stanu roślin na poletkach kontrolnych ( $0 \%$ - brak objawów fitotoksyczności, 100\% - całkowite zniszczenie roślin). Obserwacje przeprowadzono po upływie 1, 2 i 3 tygodni od daty stosowania środków chwastobójczych oraz po wykłoszeniu. Przed zbiorem obliczono obsadę kłosów na $1 \mathrm{~m}^{2}$ oraz pobrano 25 sztuk kłosów z każdego poletka w celu obliczenia liczby ziaren z kłosa. Po zbiorze pszenicy, który wykonano kombajnem poletkowym Wintersteiger Classic, ustalono wysokość plonów w przeliczeniu na 14\% wilgotności ziarna oraz masę 1000 ziaren. Wyniki opracowano używając programu ANALWAR-5.2.FR. Wykonano analizę wariancji dla poziomu istotności $\mathrm{p}=0,05$, a istotność różnic między średnimi oceniono testem Tukeya.

\section{Wyniki i dyskusja / Results and discussion}

$\mathrm{Na}$ poletkach kontrolnych, w zależności od terminu siewu i uprawianej odmiany pszenicy ozimej, wystapiło duże zróżnicowanie zachwaszczenia pod względem ilościowym na jednostce powierzchni, natomiast liczba występujących taksonów kształtowała się podobnie. Wśród gatunków chwastów dwuliściennych obserwowano najczęściej: Brassica napus var. oleifera, Matricaria maritima ssp. inodora, Centauera cyanus i Galium aparine, a $\mathrm{z}$ jednoliściennych - Apera spica-venti. Ich udział w całości zbiorowiska wynosił od 58,3 do 74,2\%. Mniej licznie pojawiały się także: Stellaria media, Thlaspi arvense i Viola arvensis, zaś pozostałe gatunki: Lamium purpureum, Capsella bursa-pastoris, Veronica hederifolia, Veronica arvensis, Papaver rhoeas w strukturze zachwaszczenia nie przekraczały $5 \%$ ogółu zbiorowiska (tab. 1, 2).

W pszenicy zasianej w terminie optymalnym, chociaż niejednakowo w badanych odmianach, panowały sprzyjające warunki do licznego i silnego rozwoju chwastów, które przed okresem spoczynku zimowego znajdowały się 
w fazie 2-6 liści, bądź w fazie rozety. W łanie odmiany Ludwig było 137,5 sztuki chwastów dwuliściennych i 68,4 sztuk $A$. spica-venti na $1 \mathrm{~m}^{2}$, a w łanie odmiany Nutka odpowiednio: 175,1 i $71,8 \mathrm{szt} . / \mathrm{m}^{2}$.
W strukturze zachwaszczania, w zasiewach obu odmian dominującą rolę stanowiły następujące gatunki: B. napus var. oleifera $\left(27,7-34,0 \mathrm{szt} . / \mathrm{m}^{2}\right)$, G. aparine $\left(18,2-23,4\right.$ szt. $\left./ \mathrm{m}^{2}\right), \quad$ M. martima ssp. inodora $(16,9$ $\left.-21,7 \mathrm{szt} . / \mathrm{m}^{2}\right)$ i C. cyanus $\left(13,9-19,1 \mathrm{szt} . / \mathrm{m}^{2}\right)$.

Tabela 1. Skuteczność herbicydów w zwalczaniu chwastów w pszenicy ozimej odmiany Ludwig (2009-2011)

Table 1. The effectiveness of weed control in the winter wheat variety Ludwig (2009-2011)

\begin{tabular}{|c|c|c|c|c|}
\hline \multirow[b]{2}{*}{$\begin{array}{l}\text { Herbicyd } \\
\text { Herbicide }\end{array}$} & \multirow{2}{*}{$\begin{array}{l}\text { Termin } \\
\text { zabiegu } \\
\text { Time } \\
\text { of } \\
\text { application }\end{array}$} & \multirow{2}{*}{$\begin{array}{c}\text { Dwuliś- } \\
\text { cienne } \\
\text { Dicot } \\
{[\%]}\end{array}$} & \multicolumn{2}{|c|}{$\begin{array}{c}\text { Skuteczność chwastobójcza - Weed control efficiency } \\
{[\%]}\end{array}$} \\
\hline & & & & \\
\hline
\end{tabular}

\begin{tabular}{|c|c|c|c|c|c|c|c|c|c|c|c|c|c|c|}
\hline \multicolumn{15}{|c|}{ Optymalny termin siewu - Optimum sowing date } \\
\hline $\begin{array}{l}\text { Kontrola }\left[\mathrm{szt} . / \mathrm{m}^{2}\right] \\
\text { Control }\left[\mathrm{pcs} / \mathrm{m}^{2}\right]\end{array}$ & - & 137,5 & 18,2 & 16,9 & 13,9 & 27,7 & 8,4 & 7,6 & 11,5 & 7,7 & 6,0 & 7,9 & 11,7 & 68,4 \\
\hline Maraton $375 \mathrm{SC}-2,0 \mathrm{l} / \mathrm{ha}$ & $\mathrm{T} 1$ & 91,8 & 90,3 & 91,7 & 90,2 & 94,4 & 88,3 & 93,5 & 94,3 & 90,2 & 92,6 & 94,1 & 90,3 & 96,6 \\
\hline Maraton $375 \mathrm{SC}-4,0 \mathrm{l} / \mathrm{ha}$ & $\mathrm{T} 1$ & 96,9 & 98,9 & 95,2 & 95,6 & 97,3 & 94,1 & 96,3 & 98,6 & 95,4 & 96,7 & 98,3 & 99,5 & 99,2 \\
\hline $\begin{array}{l}\text { Biathlon } 71,4 \mathrm{WG} \\
-0,025 \mathrm{~kg} / \mathrm{ha} \\
+ \text { Apyros } 75 \mathrm{WG} \\
-0,0065 \mathrm{~kg} / \mathrm{ha}\end{array}$ & $\mathrm{T} 2$ & 86,0 & 88,3 & 92,4 & 89,2 & 90,7 & 50,3 & 90,1 & 90,6 & 88,3 & 88,8 & 82,2 & 94,7 & 88,4 \\
\hline $\begin{array}{l}\text { Biathlon } 71,4 \mathrm{WG} \\
-0,05 \mathrm{~kg} / \mathrm{ha} \\
+ \text { Apyros } 75 \mathrm{WG} \\
-0,013 \mathrm{~kg} / \mathrm{ha}\end{array}$ & $\mathrm{T} 2$ & 91,9 & 92,5 & 97,7 & 93,3 & 96,6 & 65,2 & 97,9 & 94,3 & 91,2 & 94,6 & 90,3 & 97,5 & 94,1 \\
\hline $\begin{array}{l}\text { Mocarz } 75 \mathrm{WG} \\
-0,075 \mathrm{~kg} / \mathrm{ha} \\
+ \text { Apyros } 75 \mathrm{WG} \\
-0,0065 \mathrm{~kg} / \mathrm{ha}\end{array}$ & $\mathrm{T} 2$ & 92,7 & 90,2 & 95,4 & 94,2 & 95,8 & 90,1 & 92,7 & 92,3 & 93,9 & 90,1 & 90,8 & 94,3 & 95,4 \\
\hline $\begin{array}{l}\text { Mocarz } 75 \mathrm{WG} \\
-0,15 \mathrm{~kg} / \mathrm{ha}+ \\
\text { Apyros } 75 \mathrm{WG} \\
-0,013 \mathrm{~kg} / \mathrm{ha}\end{array}$ & $\mathrm{T} 2$ & 97,6 & 96,7 & 98,9 & 96,3 & 99,6 & 95,3 & 99,1 & 98,5 & 96,7 & 97,9 & 96,3 & 98,6 & 97,2 \\
\hline
\end{tabular}

Opóźniony termin siewu - Delayed swing date

\begin{tabular}{|c|c|c|c|c|c|c|c|c|c|c|c|c|c|c|}
\hline $\begin{array}{l}\text { Kontrola }\left[\mathrm{szt} . / \mathrm{m}^{2}\right] \\
\text { Control }\left[\mathrm{pcs} / \mathrm{m}^{2}\right]\end{array}$ & - & 96,4 & 12,7 & 13,3 & 13,1 & 7,1 & 9,0 & 5,2 & 8,6 & 3,5 & 4,1 & 7,7 & 12,1 & 38,5 \\
\hline Maraton $375 \mathrm{SC}-2,0$ 1/ha & $\mathrm{T} 1$ & 94,5 & 92,6 & 94,3 & 94,8 & 95,3 & 92,1 & 96,7 & 94,9 & 93,3 & 95,5 & 94,4 & 95,2 & 98,3 \\
\hline Maraton $375 \mathrm{SC}-4,0$ 1/ha & $\mathrm{T} 1$ & 98,8 & 98,1 & 97,5 & 100,0 & 99,7 & 96,5 & 98,3 & 100,0 & 97,2 & 100,0 & 99,3 & 100,0 & 100,0 \\
\hline $\begin{array}{l}\text { Biathlon } 71,4 \mathrm{WG} \\
-0,025 \mathrm{~kg} / \mathrm{ha} \\
+ \text { Apyros } 75 \mathrm{WG} \\
-0,0065 \mathrm{~kg} / \mathrm{ha}\end{array}$ & $\mathrm{T} 2$ & 89,1 & 91,4 & 94,5 & 91,3 & 93,7 & 55,2 & 91,6 & 93,3 & 92,8 & 92,3 & 88,1 & 96,2 & 90,3 \\
\hline $\begin{array}{l}\text { Biathlon } 71,4 \mathrm{WG} \\
-0,05 \mathrm{~kg} / \mathrm{ha}+ \\
\text { Apyros } 75 \mathrm{WG} \\
-0,013 \mathrm{~kg} / \mathrm{ha} \\
\end{array}$ & $\mathrm{T} 2$ & 94,8 & 95,7 & 99,3 & 95,5 & 98,2 & 65,4 & 99,3 & 98,8 & 98,3 & 99,2 & 93,7 & 99,9 & 96,3 \\
\hline $\begin{array}{l}\text { Mocarz } 75 \mathrm{WG} \\
-0,075 \mathrm{~kg} / \mathrm{ha} \\
+ \text { Apyros } 75 \mathrm{WG} \\
-0,0065 \mathrm{~kg} / \mathrm{ha}\end{array}$ & $\mathrm{T} 2$ & 95,3 & 94,5 & 98,7 & 96,1 & 96,7 & 93,9 & 96,3 & 94,6 & 95,9 & 93,3 & 92,8 & 95,2 & 98,5 \\
\hline $\begin{array}{l}\text { Mocarz } 75 \mathrm{WG} \\
-0,15 \mathrm{~kg} / \mathrm{ha} \\
+ \text { Apyros } 75 \mathrm{WG} \\
-0,013 \mathrm{~kg} / \mathrm{ha}\end{array}$ & $\mathrm{T} 2$ & 99,2 & 99,7 & 99,3 & 98,8 & 100,0 & 97,4 & 100,0 & 99,3 & 100,0 & 99,7 & 97,3 & 99,7 & 99,3 \\
\hline
\end{tabular}

GALAP - Galium aparine, MATIN - Matricaria maritima ssp. inodora, CENCY - Centaurea cyanus, BRSNW - Brassica napus var. oleifera, VIOAR

- Viola arvensis, LAMPU - Lamium purpureum, THLAR - Thlaspi arvense, CAPBP - Capsella bursa-pastoris, VERAR - Veronica arvensis, PAPRH -

Papaver rhoeas, STEME - Stellaria media, APESV - Apera spica-venti 
Tabela 2. Skuteczność herbicydów w zwalczaniu chwastów w pszenicy ozimej odmiany Nutka (2009-2011)

Table 2. The effectiveness of weed control in the winter wheat variety Nutka (2009-2011)

\begin{tabular}{|c|c|c|c|c|c|c|c|c|c|c|c|c|c|c|}
\hline \multirow[b]{2}{*}{$\begin{array}{l}\text { Herbicyd } \\
\text { Herbicide }\end{array}$} & \multirow{2}{*}{\begin{tabular}{|c|} 
Termin \\
zabiegu \\
Time \\
of \\
application
\end{tabular}} & \multirow{2}{*}{$\begin{array}{c}\text { Dwuliś- } \\
\text { cienne } \\
\text { Dicot } \\
{[\%]}\end{array}$} & \multicolumn{12}{|c|}{$\begin{array}{c}\text { Skuteczność chwastobójcza - Weed control efficiency } \\
{[\%]}\end{array}$} \\
\hline & & & 悹 & Z & $\begin{array}{l}z \\
z \\
z\end{array}$ & $\begin{array}{l}3 \\
\sum \\
\frac{1}{n} \\
\frac{1}{n}\end{array}$ & $\underset{\substack{d \\
ٍ}}{3}$ & 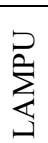 & 茎 & $\sum_{0}^{0}$ & $\frac{a}{\frac{d}{d}}$ & $\frac{\mathbb{2}}{2}$ & $\sum_{\substack{\mid=1 \\
\text { L }}}^{+1}$ & $\begin{array}{l}\overrightarrow{3} \\
\frac{\pi}{4} \\
\frac{1}{4}\end{array}$ \\
\hline
\end{tabular}

Optymalny termin siewu - Optimum sowing date

\begin{tabular}{|c|c|c|c|c|c|c|c|c|c|c|c|c|c|c|}
\hline $\begin{array}{l}\text { Kontrola }\left[\mathrm{szt} . / \mathrm{m}^{2}\right] \\
\text { Control }\left[\mathrm{pcs} / \mathrm{m}^{2}\right]\end{array}$ & - & 175,1 & 23,4 & 21,7 & 19,1 & 34,0 & 11,2 & 9,7 & 16,5 & 6,4 & 5,2 & 11,7 & 16,2 & 71,8 \\
\hline $\begin{array}{l}\text { Maraton } 375 \mathrm{SC} \\
-2,01 / \mathrm{ha}\end{array}$ & $\mathrm{T} 1$ & 91,9 & 90,6 & 91,3 & 90,5 & 94,9 & 88,3 & 93,2 & 94,7 & 90,3 & 92,1 & 94,4 & 90,2 & 96,3 \\
\hline $\begin{array}{l}\text { Maraton } 375 \mathrm{SC} \\
-4,01 / \mathrm{ha}\end{array}$ & $\mathrm{T} 1$ & 96,8 & 98,3 & 95,6 & 95,4 & 97,1 & 94,4 & 96,2 & 98,1 & 95,8 & 96,3 & 98,1 & 99,3 & 99,8 \\
\hline $\begin{array}{l}\text { Biathlon } 71,4 \mathrm{WG} \\
-0,025 \mathrm{~kg} / \mathrm{ha} \\
+ \text { Apyros } 75 \mathrm{WG} \\
-0,0065 \mathrm{~kg} / \mathrm{ha}\end{array}$ & $\mathrm{T} 2$ & 86,0 & 88,1 & 92,3 & 89,8 & 90,7 & 50,4 & 90,5 & 90,1 & 88,7 & 88,3 & 82,5 & 94,1 & 88,4 \\
\hline $\begin{array}{l}\text { Biathlon } 71,4 \mathrm{WG} \\
-0,05 \mathrm{~kg} / \mathrm{ha}+ \\
\text { Apyros } 75 \mathrm{WG} \\
-0,013 \mathrm{~kg} / \mathrm{ha}\end{array}$ & $\mathrm{T} 2$ & 91,9 & 92,8 & 97,5 & 93,6 & 96,1 & 65,7 & 97,3 & 94,2 & 91,8 & 94,1 & 90,7 & 97,3 & 94,7 \\
\hline $\begin{array}{l}\text { Mocarz } 75 \mathrm{WG} \\
-0,075 \mathrm{~kg} / \mathrm{ha} \\
+ \text { Apyros } 75 \mathrm{WG} \\
-0,0065 \mathrm{~kg} / \mathrm{ha}\end{array}$ & $\mathrm{T} 2$ & 92,6 & 90,1 & 95,3 & 94,6 & 95,8 & 90,1 & 92,3 & 92,1 & 93,4 & 90,7 & 90,1 & 94,6 & 95,2 \\
\hline $\begin{array}{l}\text { Mocarz } 75 \mathrm{WG} \\
-0,15 \mathrm{~kg} / \mathrm{ha} \\
+ \text { Apyros } 75 \mathrm{WG} \\
-0,013 \mathrm{~kg} / \mathrm{ha}\end{array}$ & $\mathrm{T} 2$ & 97,6 & 96,3 & 98,8 & 96,1 & 99,2 & 95,7 & 99,5 & 98,6 & 96,7 & 97,5 & 96,3 & 98,4 & 97,7 \\
\hline
\end{tabular}

Opóźniony termin siewu - Delayed swing date

\begin{tabular}{|c|c|c|c|c|c|c|c|c|c|c|c|c|c|c|}
\hline $\begin{array}{l}\text { Kontrola }\left[\mathrm{szt} . / \mathrm{m}^{2}\right] \\
\text { Control }\left[\mathrm{pcs} / \mathrm{m}^{2}\right]\end{array}$ & - & 113,0 & 16,1 & 18,6 & 15,5 & 7,5 & 8,3 & 6,0 & 11,2 & 4,0 & 3,6 & 8,2 & 14,0 & 45,5 \\
\hline $\begin{array}{l}\text { Maraton } 375 \mathrm{SC} \\
-2,0 \text { 1/ha }\end{array}$ & $\mathrm{T} 1$ & 94,4 & 92,3 & 94,7 & 94,1 & 95,9 & 92,2 & 96,5 & 94,2 & 93,3 & 95,8 & 94,1 & 95,2 & 98,6 \\
\hline $\begin{array}{l}\text { Maraton } 375 \mathrm{SC} \\
-4,01 / \mathrm{ha}\end{array}$ & $\mathrm{T} 1$ & 98,9 & 98,4 & 97,7 & 100,0 & 99,3 & 96,6 & 98,3 & 100,0 & 97,8 & 99,3 & 100,0 & 100,0 & 100,0 \\
\hline $\begin{array}{l}\text { Biathlon } 71,4 \mathrm{WG} \\
-0,025 \mathrm{~kg} / \mathrm{ha} \\
+ \text { Apyros } 75 \mathrm{WG} \\
-0,0065 \mathrm{~kg} / \mathrm{ha}\end{array}$ & $\mathrm{T} 2$ & 89,3 & 91,8 & 94,6 & 91,9 & 93,4 & 55,3 & 91,7 & 93,3 & 92,9 & 92,6 & 88,7 & 96,3 & 90,6 \\
\hline $\begin{array}{l}\text { Biathlon } 71,4 \mathrm{WG} \\
-0,05 \mathrm{~kg} / \mathrm{ha} \\
+ \text { Apyros } 75 \mathrm{WG} \\
-0,013 \mathrm{~kg} / \mathrm{ha}\end{array}$ & $\mathrm{T} 2$ & 94,8 & 95,3 & 99,1 & 95,8 & 98,3 & 65,2 & 99,4 & 98,7 & 98,2 & 99,1 & 93,9 & 99,4 & 96,9 \\
\hline $\begin{array}{l}\text { Mocarz } 75 \mathrm{WG} \\
-0,075 \mathrm{~kg} / \mathrm{ha} \\
+ \text { Apyros } 75 \mathrm{WG} \\
-0,0065 \mathrm{~kg} / \mathrm{ha}\end{array}$ & $\mathrm{T} 2$ & 95,2 & 94,1 & 98,3 & 96,2 & 96,5 & 93,9 & 96,8 & 94,3 & 95,8 & 93,5 & 92,3 & 95,6 & 98,4 \\
\hline $\begin{array}{l}\text { Mocarz } 75 \mathrm{WG} \\
-0,15 \mathrm{~kg} / \mathrm{ha} \\
+ \text { Apyros } 75 \mathrm{WG} \\
-0,013 \mathrm{~kg} / \mathrm{ha}\end{array}$ & $\mathrm{T} 2$ & 99,0 & 99,6 & 99,1 & 98,6 & 100,0 & 97,1 & 99,3 & 99,5 & 99,1 & 99,3 & 97,1 & 100,0 & 99,3 \\
\hline
\end{tabular}

GALAP - Galium aparine, MATIN - Matricaria maritima ssp. inodora, CENCY - Centaurea cyanus, BRSNW - Brassica napus var. oleifera, VIOAR - Viola arvensis, LAMPU - Lamium purpureum, THLAR - Thlaspi arvense, CAPBP - Capsella bursa-pastoris, VERAR - Veronica arvensis, PAPRH Papaver rhoeas, STEME - Stellaria media, APESV - Apera spica-venti 
Inaczej przedstawiało się zachwaszczenie w zasiewach opóźnionych, w których liczebność była niższa aniżeli w zasiewach optymalnych, a przed spoczynkiem zimowym pszenicy chwasty w większości znajdowały się w fazie wschodów bądź liścieni. Zarysowały się także różnice pomiędzy odmianami. Poletka odmiany Ludwig były zasiedlone przez 96,4 szt. $/ \mathrm{m}^{2}$ chwastów dwuliściennych i 38,5 szt. $/ \mathrm{m}^{2}$ A. spica-venti, a odmiany Nutka odpowiednio: 113,0 i 45,5 szt. $/ \mathrm{m}^{2}$. Podobnie, jak w pszenicy wysianej w terminie optymalnym, dominującą rolę odgrywały te same gatunki chwastów poza $B$. napus var. oleifera, który podczas zimy ulegał wymarznięciu (tab. 1, 2).

Skuteczność użytych środków chwastobójczych nie zależała od chronionej odmiany, lecz od terminu siewu pszenicy i aplikowanych dawek środków. Herbicydy zastosowane w pszenicy wysianej w optymalnym terminie ograniczały liczebność chwastów dwuliściennych w granicach od 86,0 do $97,6 \%$, a $A$. spica-venti od 88,4 do $99,2 \%$, natomiast użyte w pszenicy później wysiewanej, odpowiednio na poziomie od 89,1 do $99,7 \%$ i od 90,3 do $100 \%$. Pełne dawki herbicydów charakteryzowały się tylko nieco wyższym efektem chwastobójczym od dawek zredukowanych o 50\%. Świadczy to o tym, że występująca flora segetalna cechowała się dużą wrażliwością na zastosowane środki. Niezależnie od terminu siewu i badanej odmiany pszenicy ozimej, najwyższą skutecznością chwastobójczą charakteryzował się zastosowany w okresie jesiennym preparat Maraton 375 EC w dawce 4,0 1/ha, a wiosną, po ruszeniu wegetacji, mieszanina herbicydów Mocarz $75 \mathrm{WG}+$ Apyros $75 \mathrm{WG}$ w dawce 0,15 $+0,013 \mathrm{~kg} / \mathrm{ha}$, natomiast najniższą - Biathlon 71,4 WG + Apyros 75 WG w dawce 0,025 + 0,0065 kg/ha (tab. 3, 4).

Średnie plony ziarna pochodzące $\mathrm{z}$ obiektów chronionych środkami chwastobójczymi, z zasiewów przeprowadzonych $\mathrm{w}$ terminie optymalnym, $\mathrm{u}$ obu odmian pszenicy kształtowały się na zbliżonym poziomie i były istotnie wyższe niż z zasiewów opóźnionych. Rośliny odmiany Ludwig zareagowały w niższym stopniu obniżką plonów na opóźniony siew pszenicy $(5,8 \%)$ od roślin odmiany Nutka (16,7\%). W obrębie kombinacji z użyciem pełnych i o połowę obniżonych dawek herbicydów, wielkość plonów ziarna badanych odmian nie ulegała istotnemu zróżnicowaniu. Istotnie niżej, ale niejednakowo u obu odmian, kształtowały się plony na obiektach kontrolnych. Ich wielkość, przeciwnie niż z obiektów chronionych herbicydami, przyjmowała wyższe wartości w przypadku zasiewów opóźnionych niż optymalnych. Poza tym rośliny odmiany Ludwig, niezależnie od badanych czynników agrotechnicznych cechowały się zawsze wyższymi plonami ziarna niż odmiany Nutka. W przeprowadzonych badaniach określono również wpływ herbicydów na strukturę plonu obu odmian pszenicy ozimej. Dowiedziono, że ziarno badanych odmian zebrane $\mathrm{z}$ obiektów opryskiwanych środkami chwastobójczymi, ale tylko z zasiewów pszenicy wykonanych $\mathrm{w}$ terminie optymalnym, miało istotnie wyższą masę 1000 ziaren niż na obiektach kontrolnych. Prawidłowość ta nie wystąiła w przypadku opóźnienia terminu siewu. Wartość tej cechy u ziarna $\mathrm{z}$ zasiewów terminowych była o ponad $15 \%$ większa aniżeli z zasiewów opóźnionych.
Uwzględnione czynniki agrotechniczne nie miały wpływu na liczbe ziaren w kłosie, natomiast istotnie różnicowały obsadę kłosów na jednostce powierzchni. Na poletkach kontrolnych średnia liczba kłosów była o 14\% wyższa w pszenicach zasianych w terminie opóźnionym niż optymalnym, zaś na opryskiwanych herbicydami powyższe relacje ułożyły się odwrotnie. Poza tym liczba kłosów na jednostce powierzchni, zarówno na poletkach kontrolnych, jak też chronionych herbicydami była zawsze wyższa w zasiewach odmiany Ludwig.

Wyniki badań Kapelusznego i Pawłowskiego (1978), Roli (1982), Christiansena i Rasmussena (1997) potwierdzają, że spośród występujących agrofagów, największe zagrożenie dla plonowania pszenicy stanowi konkurencyjne oddziaływanie chwastów. Zdaniem cytowanych autorów obecność w łanie pszenicy takich gatunków chwastów, jak: G. aparine, M. maritima ssp. inodora, $C$. cyanus czy A. spica-venti, w nasileniu od 5 do $25 \mathrm{szt} . / \mathrm{m}^{2}$ może powodować straty plonów ziarna do $66 \%$. Wyszczególnione gatunki wystapiły również w prezentowanych badaniach, lecz ich wpływ na wielkość plonu był mniejszy, co można wiązać z faktem, że pszenicę uprawiano na dobrych glebach, po odpowiednim przedplonie, gdzie zastosowano wysokie dawki nawozów mineralnych i pełną ochronę przed chorobami i szkodnikami. Poza tym, jak wyjaśnia Adamczewski (1988), zróżnicowane zbiorowiska segetalne wywierają mniejszy wpływ na plonowanie aniżeli kompensacja pojedynczych gatunków chwastów. Również odmienną zdolność konkurencyjną odmian pszenicy ozimej wobec chwastów potwierdzają badania przeprowadzone przez Kraskę (2006), który stwierdził, że rośliny odmiany Tonacja w interfazie strzelanie w źdźbłokłoszenie zawierało w łanie o 55\% więcej chwastów od odmiany Turnia. Do podobnych wniosków doszli Kaczmarek i wsp. (2010), którzy stwierdzili większą konkurencyjność odmiany Zyta w stosunku do chwastów od krótkosłomej odmiany Kris.

Z doniesień prezentowanych przez Domaradzkiego i Rolę (2001), Domaradzkiego i wsp. (2003), Drzewieckiego i Pietrygę (2006), Kraskę (2006) oraz Matysiak (2008) wynika, że zredukowanie o 50\% dawek herbicydów nie musi skutkować pogorszeniem efektu chwastobójczego, a tym samym obniżeniem plonowania pszenicy. Według autorów, efektywność obniżonych dawek środków chwastobójczych zależała od zastosowanej substancji czynnej, gatunków i faz rozwojowych chwastów, techniki wykonania zabiegu oraz od przebiegu warunków pogodowych.

W dostępnej literaturze nie znaleziono wyników dotyczących wpływu tych samych herbicydów zastosowanych w różnych terminach siewu pszenicy na jej plonowanie i strukturę plonu. Niemniej jednak wielu badaczy wskazało, że wysokość plonu i jego struktura determinowane są w głównej mierze stanem zachwaszczenia. Rola (1982) podaje, że w wyniku zachwaszczenia następowała obniżka plonu ziarna oraz redukcja wszystkich elementów struktury plonu, natomiast Kapeluszny i Pawłowski (1978) wyrażają pogląd, że wraz ze wzrostem zachwaszczenia następował spadek obsady źdźbeł kłosonośnych na jednostce powierzchni, natomiast masa 1000 ziaren i liczba 
Tabela 3. Wpływ herbicydów na strukturę i plon ziarna odmian pszenicy ozimej (2009-2011) zasianej w terminie optymalnym

Table 3. The effect of herbicides on the structure and grain yield of winter wheat cultivars (2009-2011) sown at the optimum period

\begin{tabular}{|c|c|c|c|c|c|c|c|c|}
\hline \multirow[t]{2}{*}{$\begin{array}{l}\text { Herbicyd } \\
\text { Herbicide }\end{array}$} & \multicolumn{2}{|c|}{$\begin{array}{l}\text { Liczba kłosów } \\
{\left[\mathrm{szt} . / \mathrm{m}^{2}\right]} \\
\text { Number of ear } \\
{\left[\mathrm{pcs} / \mathrm{m}^{2}\right]}\end{array}$} & \multicolumn{2}{|c|}{$\begin{array}{c}\text { Liczba ziaren w kłosie } \\
\text { [szt.] } \\
\text { Number of grains } \\
\text { per spike } \\
\text { [pcs] }\end{array}$} & \multicolumn{2}{|c|}{$\begin{array}{c}\text { Masa } 1000 \text { ziaren } \\
\text { Weight of } 1000 \text { grains } \\
{[\mathrm{g}]}\end{array}$} & \multicolumn{2}{|c|}{$\begin{array}{l}\text { Plon } \\
\text { Yield of grain } \\
{[\mathrm{t} / \mathrm{ha}]}\end{array}$} \\
\hline & Ludwig & Nutka & Ludwig & Nutka & Ludwig & Nutka & Ludwig & Nutka \\
\hline $\begin{array}{l}\text { Kontrola }\left[\mathrm{szt} . / \mathrm{m}^{2}\right] \\
\text { Control }\left[\mathrm{pcs} / \mathrm{m}^{2}\right]\end{array}$ & 349,7 & 317,3 & 46,9 & 48,7 & 48,7 & 44,36 & 5,63 & 4,84 \\
\hline $\begin{array}{l}\text { Maraton } 375 \mathrm{SC} \\
-2,0 \text { 1/ha }\end{array}$ & 520,0 & 532,7 & 46,4 & 49,8 & 51,8 & 47,07 & 8,58 & 8,24 \\
\hline $\begin{array}{l}\text { Maraton } 375 \mathrm{SC} \\
-4,01 / \mathrm{ha}\end{array}$ & 549,7 & 556,0 & 47,0 & 50,2 & 52,6 & 47,27 & 8,99 & 8,67 \\
\hline $\begin{array}{l}\text { Biathlon } 71,4 \mathrm{WG} \\
-0,025 \mathrm{~kg} / \mathrm{ha}+ \\
\text { Apyros } 75 \mathrm{WG} \\
-0,0065 \mathrm{~kg} / \mathrm{ha}\end{array}$ & 520,7 & 528,7 & 46,3 & 48,9 & 52,8 & 47,37 & 8,49 & 8,13 \\
\hline $\begin{array}{l}\text { Biathlon } 71,4 \mathrm{WG} \\
-0,05 \mathrm{~kg} / \mathrm{ha}+ \\
\text { Apyros } 75 \mathrm{WG} \\
-0,013 \mathrm{~kg} / \mathrm{ha} \\
\end{array}$ & 536,7 & 547,7 & 46,2 & 49,2 & 52,2 & 47,86 & 8,62 & 8,54 \\
\hline $\begin{array}{l}\text { Mocarz } 75 \mathrm{WG} \\
-0,075 \mathrm{~kg} / \mathrm{ha}+ \\
\text { Apyros } 75 \mathrm{WG} \\
-0,0065 \mathrm{~kg} / \mathrm{ha} \\
\end{array}$ & 526,3 & 523,0 & 46,7 & 50,0 & 52,6 & 47,87 & 8,61 & 8,17 \\
\hline $\begin{array}{l}\text { Mocarz } 75 \mathrm{WG} \\
-0,15 \mathrm{~kg} / \mathrm{ha}+ \\
\text { Apyros } 75 \mathrm{WG} \\
-0,013 \mathrm{~kg} / \mathrm{ha}\end{array}$ & 542,0 & 552,3 & 46,8 & 48,9 & 53,4 & 48,54 & 8,83 & 8,58 \\
\hline $\operatorname{NIR}(0,05)-\operatorname{LSD}(0.05)$ & 22,09 & 40,99 & r.n. & r.n. & 2,07 & 2,59 & 0,45 & 0,66 \\
\hline
\end{tabular}

Ludwig, Nutka - odmiany pszenicy ozimej - winter wheat varieties

r.n. - różnice nieistotne - not significant differences

Tabela 4. Wpływ herbicydów na strukturę i plon ziarna odmian pszenicy ozimej (2009-2011) zasianej w terminie opóźnionym Table 4. The effect of herbicides on the structure and grain yield cultivars (2009-2011) sown at delayed period

\begin{tabular}{|c|c|c|c|c|c|c|c|c|}
\hline \multirow[t]{2}{*}{$\begin{array}{l}\text { Herbicyd } \\
\text { Herbicide }\end{array}$} & \multicolumn{2}{|c|}{$\begin{array}{l}\text { Liczba kłosów } \\
{\left[\mathrm{szt} . / \mathrm{m}^{2}\right]} \\
\text { Number of ear } \\
{\left[\mathrm{pcs} / \mathrm{m}^{2}\right]}\end{array}$} & \multicolumn{2}{|c|}{$\begin{array}{l}\text { Liczba ziaren w kłosie } \\
\text { [szt.] } \\
\text { Number of grains per spike } \\
\text { [pcs] }\end{array}$} & \multicolumn{2}{|c|}{$\begin{array}{c}\text { Masa } 1000 \text { ziaren } \\
\text { Weight of } 1000 \text { grains } \\
{[\mathrm{g}]}\end{array}$} & \multicolumn{2}{|c|}{$\begin{array}{l}\text { Plon } \\
\text { Yield of grain } \\
{[\mathrm{t} / \mathrm{ha}]}\end{array}$} \\
\hline & Ludwig & Nutka & Ludwig & Nutka & Ludwig & Nutka & Ludwig & Nutka \\
\hline 1 & 2 & 3 & 4 & 5 & 6 & 7 & 8 & 9 \\
\hline $\begin{array}{l}\text { Kontrola }\left[\mathrm{szt} . / \mathrm{m}^{2}\right] \\
\text { Control }\left[\mathrm{pcs} / \mathrm{m}^{2}\right]\end{array}$ & 401,0 & 359,7 & 47,4 & 46,8 & 44,8 & 40,00 & 6,31 & 5,53 \\
\hline $\begin{array}{l}\text { Maraton } 375 \mathrm{SC} \\
-2,01 / \mathrm{ha}\end{array}$ & 517,0 & 477,0 & 48,4 & 48,4 & 45,3 & 41,04 & 8,11 & 7,35 \\
\hline $\begin{array}{l}\text { Maraton } 375 \mathrm{SC} \\
-4,0 \mathrm{l} / \mathrm{ha}\end{array}$ & 536,0 & 465,0 & 48,5 & 49,6 & 45,2 & 41,17 & 8,41 & 7,13 \\
\hline $\begin{array}{l}\text { Biathlon } 71,4 \mathrm{WG} \\
-0,025 \mathrm{~kg} / \mathrm{ha} \\
+ \text { Apyros } 75 \mathrm{WG} \\
-0,0065 \mathrm{~kg} / \mathrm{ha}\end{array}$ & 517,7 & 452,2 & 47,5 & 50,1 & 44,9 & 40,90 & 8,12 & 7,23 \\
\hline $\begin{array}{l}\text { Biathlon } 71,4 \mathrm{WG} \\
-0,05 \mathrm{~kg} / \mathrm{ha} \\
+ \text { Apyros } 75 \mathrm{WG} \\
-0,013 \mathrm{~kg} / \mathrm{ha}\end{array}$ & 526,3 & 468,3 & 47,7 & 49,0 & 45,6 & 40,90 & 8,33 & 7,39 \\
\hline
\end{tabular}




\begin{tabular}{l|c|c|c|c|c|c|c|c}
\hline \multicolumn{1}{c|}{} & 2 & 3 & 4 & 5 & 6 & 7 & 8 & 9 \\
\hline $\begin{array}{l}\text { Mocarz 75 WG } \\
\begin{array}{l}0,075 \mathrm{~kg} / \mathrm{ha} \\
+ \text { Apyros 75 WG } \\
0,0065 \mathrm{~kg} / \mathrm{ha}\end{array}\end{array}$ & 516,3 & 462,3 & 48,3 & 48,7 & 45,2 & 41,63 & 8,12 & 7,12 \\
\hline $\begin{array}{l}\text { Mocarz 75 WG } \\
-0,15 \mathrm{~kg} / \mathrm{ha} \\
+ \text { Apyros 75 WG } \\
-0,013 \mathrm{~kg} / \mathrm{ha}\end{array}$ & 534,0 & 478,0 & 48,5 & 48,3 & 45,7 & 41,57 & 8,41 & 7,41 \\
\hline $\begin{array}{l}\text { NIR }(0,05) \\
\text { LSD }(0.05)\end{array}$ & 22,70 & 28,02 & r.n. & r.n. & r.n. & r.n. & 0,39 & 0,55 \\
\hline
\end{tabular}

Ludwig, Nutka - odmiany pszenicy ozimej - winter wheat varieties r.n. - różnice nieistotne - not significant differences

ziaren w kłosie nie różniły się w porównaniu z odchwaszczaną kontrolą. Z kolei badania Podolskiej (1997, 1999) potwierdzają, że w miarę opóźnienia terminu siewu pszenicy zmniejszała się obsada kłosów na $\mathrm{m}^{2}$, plon ziarna z kłosa i liczba ziaren z rośliny, natomiast masa 1000 ziaren i liczba ziaren w kłosie pozostawały bez zmian.

\section{Wnioski / Conclusions}

1. Terminy siewu pszenicy nie miały wpływu na liczbę występujących gatunków chwastów, natomiast różnicowały ich obsadę na jednostce powierzchni. W optymalnym terminie siewu w przeciwieństwie do opóźnionego, notowano największe zachwaszczenie pszenicy, a odmiana Ludwig charakteryzowała się wyższą zdolnością konkurencyjną w stosunku do chwastów od odmiany Nutka.
2. Zastosowane herbicydy, niezależnie od terminu siewu pszenicy, zarówno w pełnych, jak i zredukowanych dawkach, cechowała wysoka skuteczność chwastobójcza.

3. Analiza struktury plonów na obiektach tratowanych środkami chwastobójczymi wykazała, że w obu terminach zasiewów pszenicy istotnie zwiększała się obsada kłosów na $\mathrm{m}^{2}$, natomiast liczba ziaren $\mathrm{w}$ kłosie nie uległa zmianom w porównaniu $\mathrm{z}$ obiektami kontrolnymi. Optymalny termin siewu skutkował wzrostem masy 1000 ziaren w porównaniu do terminu opóźnionego.

4. Na poletkach chronionych chemicznie uzyskano istotny, chociaż niejednakowy przyrost plonów ziarna w stosunku do poletek kontrolnych. Korzystniej plonowała pszenica $\mathrm{z}$ zasiewów optymalnych, a odmiana Ludwig cechowała się większymi i bardziej stabilnymi plonami ziarna aniżeli odmiana Nutka.

\section{Literatura / References}

Adamczewski K. 1988. Zalety i wady chemicznego zwalczania chwastów. Materiały 28. Sesji Nauk. Inst. Ochr. Roślin, cz. 1: 95-108.

Christiansen S., Rasmussen G. 1997. Crop weed competition, herbicide performance and decision makings in cereals. p. 50. 10th European Weed Research Society Symposium. Poznań, 22-26.06.1997, 201 pp.

Domaradzki K. 2006. Efektywność regulacji zachwaszczenia zbóż w aspekcie ograniczania dawek herbicydów oraz wybranych czynników agroekologicznych. Monografie i Rozprawy Naukowe 17. Instytut Uprawy Nawożenia i Gleboznawstwa - Państwowy Instytut Badawczy, Puławy, 111 ss.

Domaradzki K., Kieloch R., Rola H. 2003. Skuteczność herbicydów w zależności od dawki i fazy rozwojowej chwastów. [The effectiveness of herbicides in correlation to dose and growth stage of weeds]. Prog. Plant Prot./Post. Ochr. Roślin 43 (1): $109-114$.

Domaradzki K., Rola H. 2001. Ekologiczno-agronomiczne aspekty stosowania niższych dawek herbicydów w regulacji zachwaszczenia zbóż. [Ecological and agronomic aspects of application lower rates of herbicides in regulation of weed infestation in cereals]. Prog. Plant Prot./Post. Ochr. Roślin 41 (1): 229-239.

Drzewiecki S., Pietryga J. 2006. Efektywność stosowania zmniejszonych dawek herbicydów w warunkach zróżnicowanego nawożenia azotowego oraz wpływu na cechy jakościowe ziarna pszenicy ozimej. [Effectiveness of reduced doses of herbicide Rokituron D $470 \mathrm{SC}$ on quality parameters of winter wheat grain at different level of nitrogen]. Prog. Plant Prot./Post. Ochr. Roślin 46 (2): $174-178$.

Feledyn-Szewczyk B., Duer I. 2005. Konkurencyjność kilku odmian pszenicy ozimej uprawianej w ekologicznym systemie produkcji w stosunku do chwastów. [Weed competitiveness of some winter wheat varieties cultivated in organic crop production system]. Prog. Plant Prot./Post. Ochr. Roślin 45 (1): 126-133.

Kaczmarek S., Matysiak K., Kardasz P. 2010. Wpływ obniżonych dawek tritosulfuronu i dikamby na zachwaszczenie i plonowanie pszenicy ozimej. Pam. Puł. 152: 103-111.

Kapeluszny J., Pawłowski F. 1978. Próba określenia progów szkodliwości chabra bławatka i maruny bezwonnej w łanie pszenicy ozimej. Rocz. Nauk Rol., Seria A, 103 (2): 25-33.

Kraska P. 2006. Wpływ zróżnicowanych dawek herbicydów na zachwaszczenie pszenicy ozimej. [The influence of different herbicides doses on winter wheat weed infestation]. Prog. Plant Prot./Post. Ochr. Roślin 46 (2): 256-260. 
Matysiak K. 2008. Ocena stosowania obniżonych dawek wybranych herbicydów z grupy sulfonylomoczników w pszenicy jarej i jęczmieniu jarym. [Evaluation of reduced doses of sulfonylurea herbicides in spring cereals]. Prog. Plant Prot./Post. Ochr. Roślin 48 (3): 1150-1155.

Parylak D., Zawieja J., Jędruszczak M., Stupnicka-Rodzynkiewicz E., Dąbkowska T., Snarska K. 2006. Wykorzystanie zasiewów mieszanych, właściwości odmian lub zjawiska allelopatii w ograniczaniu zachwaszczenia. [Use of the mixed crops, cultivar properties or allelopathy in weed control]. Prog. Plant Prot./Post. Ochr. Roślin 46 (1): 33-44.

Pietryga J., Drzewiecki S. 2007. Redukcja dawek herbicydów w warunkach zróżnicowanego nawożenia azotowego a wysokość i jakość plonowania pszenicy jarej. [Reduction of herbicide doses in various conditions of nitrogen fertilization of spring wheat and their influence on grain yield - quantity and quality]. Prog. Plant Prot./Post. Ochr. Roślin 47 (3): 234-237.

Podolska G. 1997. Redukcja odmian i rodów pszenicy ozimej na wybrane czynniki agrotechniczne. Cz. II. Wpływ terminu siewu na plon i strukturę plonu nowych odmian i rodów pszenicy ozimej. Biul. Instytutu Hodowli i Aklimatyzacji Roślin 204: 163-168.

Podolska G. 1999. Budowa i wydajność łanu pszenicy ozimej w zależności od wybranych czynników agrotechnicznych i modelu rośliny. Rozprawa habilitacyjna. Pam. Puł. 116, 133 ss.

Rola H. 1982. Zjawisko konkurencji wśród roślin i jej skutki na przykładzie wybranych gatunków chwastów występujących w pszenicy ozimej. Wydawnictwo Instytutu Uprawy Nawożenia i Gleboznawstwa, Puławy R (162), 61 ss.

Skrzypczak G., Adamczewski K. 2002. Najgroźniejsze chwasty świata w roślinach uprawnych w XXI wieku. [The worst weeds in arable crops in XXI century]. Prog. Plant Prot./Post. Ochr. Roślin 42 (1): 358-367. 